\title{
Prevalence of Clinical Mastitis due to $E$. coli in Bovines
}

\section{R. Navaneethan, S. Saravanan", P. Suresh, K.K. Ponnuswamy and K.M. Palanivel}

Department of Veterinary Preventive Medicine, Veterinary College and Research Institute, Namakkal-2, Tamil Nadu Veterinary and Animal Sciences University, Tamil Nadu, India

*Corresponding author

\section{A B S T R A C T}

Keywords

Clinical mastitis, $E$. coli, prevalence, PCR.

\section{Article Info}

Accepted:

04 September 2017

Available Online:

10 October 2017
Mastitis, an economically important disease causes heavy economic losses in dairy cattle associated with poor quality and quantity of milk, milk discard after treatment and increased cost of veterinary services. Escherichia coli is reported to be the major environmental pathogen associated with clinical mastitis. Out of 104 milk samples collected from clinical mastitis cows brought to TVCC, VCRI, Namakkal, the prevalence mastitis due to $E$. coli was found to be $10.57 \%$ for $E$. coli identified by isolation on selective media namely eosine methylene blue agar and MacConkey agar and confirmation by employing polymerase chain reaction (PCR).

\section{Introduction}

Mastitis is one among those major reasons causing substantial loss to the dairy farmers, worldwide, resulting in 30.0 per cent less productivity per quarter and 15 per cent production per cow (Radostits et al., 2000), and loss of milk yield is estimated to range from 100 to $500 \mathrm{~kg} / \mathrm{cow}$ per lactation. Globally, mastitis accounts for about 38.0 per cent of the total direct costs of the common production diseases (Kossaibati and Esslemont, 1997). Annual economic losses due to clinical mastitis alone pegged at INR 3014.35 crores (NAAS, 2013).

Clinical mastitis is recognized by abnormal milk, gland swelling and /or systemic illness and the reduction in milk production attributed to clinical mastitis could be 30.0 percent of the total losses (Philpot and Nickerson, 1991 and Philip et al., 1993). Clinical mastitis can be peracute, acute, subacute and chronic, caused by coliforms like Escherichia coli, Klebsiella pneumoniae, $K$. oxytoca, Enterobacte raerogenes and streptococci.

However, E. coli is reported to be the commonest pathogens in environmental mastitis resulting in sudden onset of fever, loss of appetite, diarrhea, toxaemia and the infected quarter show swelling, pain with discharge of watery or bloody milk or milk with large thick clots. This paper reports the prevalence of $E$. coli in bovines at cow and 
quarter level determined by isolation and identification and confirmation by molecular technique.

\section{Materials and Methods}

A total of 136 milk samples from 104 clinical mastitic cases were collected for the period from October 2016 to March 2017 at Teaching Veterinary Clinical Complex (TVCC), Veterinary College and Research Institute, Namakkal.

A first few squirts of milk from each quarter were discarded and the second squirt of milk was collected in a sterile nutrient broth tube and incubated at $37^{\circ} \mathrm{Cfor} 5$-6hours, the loop was flamed and the sample is streaked in all selective media, Eosin methylene blue and MacConkey agar (Hi-media, Mumbai) and the plates were incubated at $37^{\circ} \mathrm{C}$ for 24 hours (Quinn et al., 1994). The colonies from the isolates were identified by Gram's staining technique as recommended by the manufacturer's kit (Himedia, Mumbai)

The sample DNA was extracted from the isolates of clinical mastitic cases by using polyethylene glycol (PEG) as recommended by Chomczynski et al., (2006). Colonies from the isolates were transferred to $100 \mu$ of nuclease free water and then mixed with $900 \mu 1$ of PEG reagent. The mixture was vortexed for 2-3 min, incubated in water bath at $90^{\circ} \mathrm{C}$ for $15 \mathrm{~min}$. and then centrifuged at $12,000 \mathrm{rpm}$ for $10 \mathrm{~min}$. Then $3 \mu \mathrm{l}$ of this lysate was transferred directly to PCR reaction mixture for amplification. The primers custom synthesized (Bioserve, India) were utilized for amplification of the mastitis causing E. coli targeting 16s ribosomal RNA gene at 585bp (Hassan et al., 2014) and were forward: 5'-GAC CTC GGT TTA GTT CAC AGA-3' and reverse: 5'-CAC ACG CTG ACG CTG ACC-3'. The cycling conditions were initial denaturation- $95^{\circ} \mathrm{C} / 180 \mathrm{sec}$, denaturation- $94^{\circ} \mathrm{C} / 45 \mathrm{sec}$, annealing $58^{\circ} \mathrm{C} / 45$ sec, extension- $73^{\circ} \mathrm{C} / 60$ sec with 30 cycles and final extension- $72^{\circ} \mathrm{C} / 180 \mathrm{sec}$. The amplified products were electrophoresed in 1.5 per cent agarose gel and specific bands were visualized under U-V illumination by gel documentation system.

\section{Results and Discussion}

The bacterial pathogens from the milk samples were identified by isolation on specific media as isolation and identification of causative pathogens is still considered to be the gold standard (Radostitis et al., 2000).

The colony characteristics of isolates specific to E. coli on EMB agar was identified as bluish green colonies with metallic sheen (Plate 1and 2) and MacConkey agar as bright pink lactose fermenting colonies. These findings are in accordance with that described by Quinn et al., (1999), and Hogan and Smith (2003).

The prevalence of $E$. coli in clinical mastitis at cow and quarter levels was identified to be 10.57 and 10.2 per cent, respectively. This finding is in agreement with that (7.69 \%) observed by Akhtar et al., (2003), whereas, a high prevalence than that in this study was recorded by Balakrishnan et al., (2004), Das and Joseph (2005), Sumathi et al., (2008) and Chandrasekaran et al., (2014) with 27.5, 17.44, 20.0 and 45. 89 per cent, respectively in Tamil Nadu and other states.

The isolates of $E$. coli from clinical mastitic cases were confirmed by PCR (Figure 1) which is found to be the most appropriate technique for the species identification of mastitic pathogens that are difficult to detect by conventional methods (Mahmmod et al., 2013) with high sensitivity (Steele et al., 2015) and high correlation rates with culture (Cervinkova et al., 2013).The prevalence of $E$. coli in this report could be associated with poor hygienic conditions as these bacteria 
being part of normal bovine intestinal flora, contaminate the environment via faeces and during puerperal period, the cow is especially sensitive to coliform infections due to low immunity at that time (Pyorala, 1995 and Radostitis, 2000).

Plate.1 Bright pink lactose fermenting colonies of E. coli on MacConkey agar

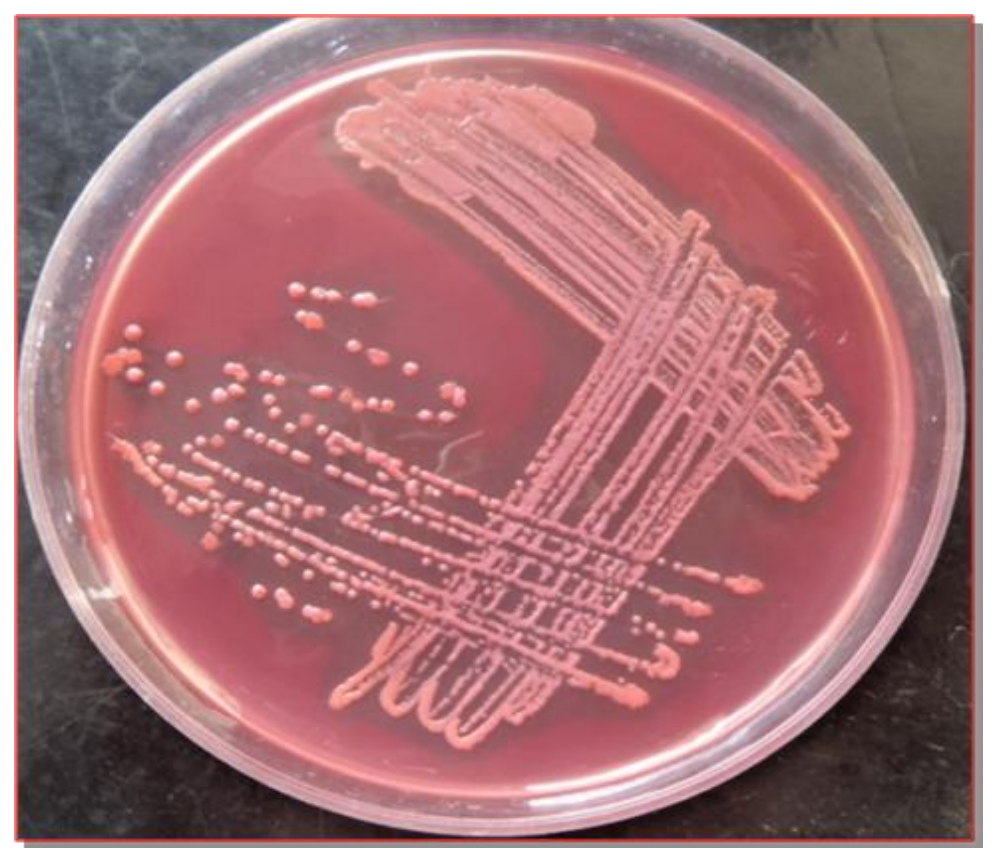

Plate.2 Greeinsh blue colonies with metallic sheen of E. coli on Eosine methylene blue agar

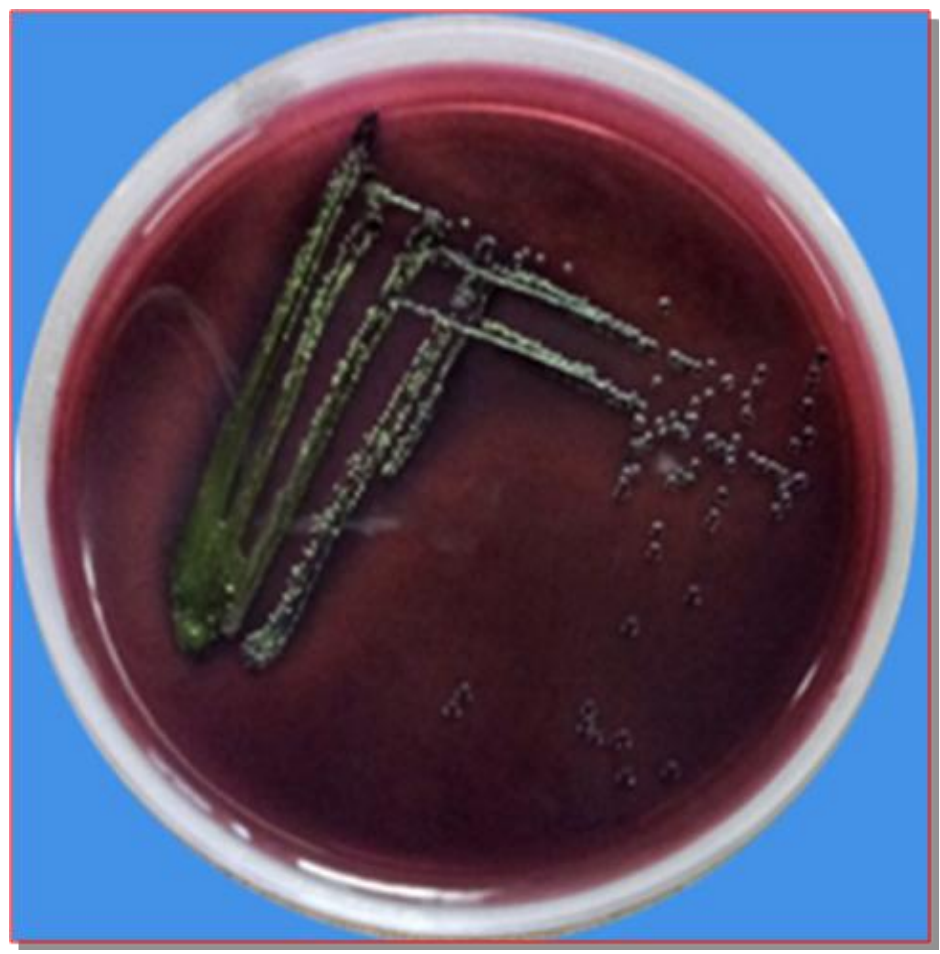


Fig.1 PCR amplified products of 16s ribosomal RNA gene of E. coli in 1.5 per cent agarose gel showing bands at $585 \mathrm{bp}$

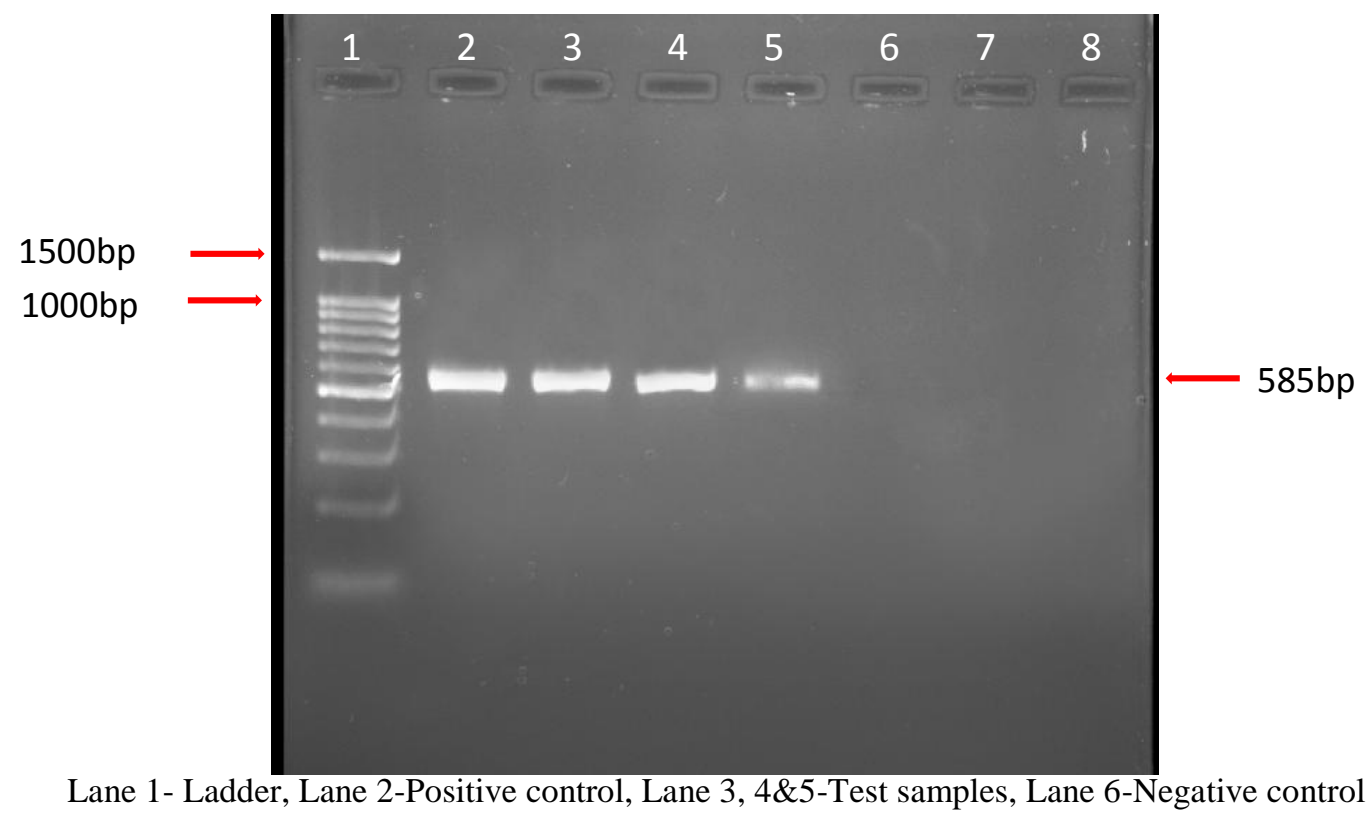

A high prevalence of $E$. coli was detected in right hind (14.8\%) and left hind quarter $(10.6 \%)$ followed by left fore $(9.3 \%)$ and right fore quarter $(6.6 \%)$. This finding is in agreement with that of Mekibib et al., (2010) who reported a high prevalence in hind quarter, in contrast, Khanal et al., (2013) and Kavitha et al., (2009) reported a high prevalence in four quarters. The high prevalence in hind quarters might presumably be associated with increased chance of hind quarters being soiled with urine and faces or by the tail leading to poor udder management (Hogan et al., 2003).

It is concluded that E. coli is one of the commonest pathogens in clinical mastitis originating from the environment of cow associated with poor hygiene in the house, poor disposal of the litter, udder washing, lack of post teat dipping, indiscriminate usage of antibiotics and lack of awareness, and could lead to severe per acute or acute and chronic mastitis failing to yield response to the treatment. Hence early diagnosis by isolation and selection of antibiotics by antibiogram is essential in the successful control of coliform mastitis due to $E$. coli.

\section{Acknowledgement}

The authors are grateful to the Tamil Nadu Veterinary and Animal Sciences University, Chennai, Tamil Nadu, India for providing necessary financial assistance to carry out this research programme and the Dean of Veterinary College and Research Institute, Namakkal, Tamil Nadu, India for providing immense support and necessary facilities to carry out this research work.

\section{References}

Akhtar, M.H., G.P. Roy, A.P. Singh, B.K. Sinha, A. Kumar and Kumar, R. 2003. In: Proceeding of $4^{\text {th }}$ Round table conference on mastitis, Palampur, H.P. (India), pp. 178-184.

Balakrishnan, G., M.M. Unny, N. Dorairajan, Subramiyan, M. 2004. Studies on bovine mastitis at Namakkal. Indian Veterinary Journal, 81: 1166-1167. 
Cervinkova, D., H. Vlkova, I. Bordocova, J. Makovcova, V. Babak, A. Lorencova, I. Vrtkova, D. Marosevic and Jaglic, Z. 2013. Prevalence of mastitis pathogens in milk from clinically healthy cows. Veterinarnimedicina, 58: 567-575.

Chandrasekaran, D., A.P. Nambi, P.S. Thirunavukkarasan, S. Vairamuthu, P. Venkatesan and Thirumurugan, K. G. 2014. A study on treatment of resistant mastitis in dairy cows. Journal of Applied and Natural Science, 6: 786-791.

Das, P.K., and Joseph, E. 2005. Identification and antibigram of microbes associated with buffalo mastitis in Jabalpur, Madhya Pradesh, India. Buffalo Bulletin, 24: 3-9.

Hassan, J., M.S. Parvej, M.B. Rahman, M.S.R. Khan, M.T. Rahman, T. Kamal, Nazir, K. 2014. Prevalence and characterization of Escherichia coli from rectal swab of apparently healthy cattle in Mymensingh, Bangladesh. Microbes and Health, 3: 12-14.

Hogan, J., and Smith, K.L. 2003. Coliform mastitis. Veterinary Research, 34: 507-519.

Kavitha, L., K. Rajesh, K. Suresh, K. Satheesh and Syamasundar, N. 2009. Buffalo mastitis - risk factors. Buffalo bulletin, 28: 134-168.

Khanal, T., and Pandit, A. 2013. Assessment of sub-clinical mastitis and its associatedrisk factors in dairy livestock of Lamjung, Nepal. International Journal of Infection and Microbiology, 2:49-54.

Kossaibati, M.A., and Esslemont, R.J. 1997. The costs of production diseases in dairy herds in England. Veterinary Journal, 154: 41-51.

Mahmmod, Y.S., I.C. Klaas, S.S. Katholm and Toft, N. 2013. Effect of presampling procedures on real-time PCR used for diagnosis of intramammary infections with
Staphylococcus aureus in dairy cows at routine milk recordings. Journal of Dairy Science, 96: 2226-2233.

Mekibib, B., M. Furgasa, F. Abunna, B. Megersa and Regassa, A. 2010. Bovine mastitis prevalence, risk factors and major pathogens in dairy farms of Holeta town, central Ethiopia. Veterinary world, 3: 397403.

NAAS, 2013. Mastitis Management in Dairy Animals. Policy Paper No. 61, National Academy of Agricultural Sciences, New Delhi: $12 \mathrm{p}$.

Philip, M., N. Ruben, Gonzalez, J. David, Wilson and Hong, R. 1993. Procedures for mastitis diagnosis and control. In the Vet. Clinics of North America: Food animal practice: Update of bovine mastitis, 9 (3): 445.

Philpot, W.N., and Nickerson, S.C. 1991. Mastitis attack. Surge International - Babson Bros. Co. Naperville, Illinois, U.S.A.

Piotr, C., and Michal, R. 2006. Alkaline polyethylene glycol based method for DNA isolation from bacteria, tissue samples and whole blood. Biotechniques, 40: 193- 199.

Quinn, P.J., M.E. Carter, B.K. Markey and Carter, G.R. 1994. Clinical Veterinary Micobiology. Mosby. Yearbool Europe limited.

Steele, N.M., J.H. Williamson, R.A. Laven and Hillerton, J.E. 2015. Using polymerase chain reaction to identify Streptococcus uberis in bovine milk. Proceeding of the NewZealand Society of Animal Production, 75:1.

Sumathi, B.R., B.M. Veeregowda and Gomes, R. 2008. Prevalence and antibiogram profile of bacterial isolates from clinical bovine mastitis. Veterinary World, 1: 237-238.

\section{How to cite this article:}

Navaneethan, R., S. Saravanan, P. Suresh, K.K. Ponnuswamy and Palanivel, K.M. 2017. Prevalence of Clinical Mastitis due to E. coli in Bovines. Int.J.Curr.Microbiol.App.Sci. 6(10): 405-409. doi: https://doi.org/10.20546/ijcmas.2017.610.050 